\title{
Analisa Kandungan Logam Timbal (Pb) Dan Kromium (Cr) Pada Kreco (Pila ampullacea) Di Sepanjang Sungai Rungkut Surabaya
}

\author{
Muhammad Adji Agus Darmawan ${ }^{1}$, Ary Andini ${ }^{1}$, Indah Lestari ${ }^{2}$ \\ ${ }^{1}$ Program Studi D-IV Analis Kesehatan, Universitas Nahdlatul Ulama Surabaya \\ ${ }^{2}$ Program Studi D-IV Analis Kesehatan, Poltekkes Kemenkes Surabaya \\ e-mail: \\ Adjie.nk15@unusa.student.ac.id \\ aryandini@unusa.ac.id \\ indahlestari@unusa.ac.id
}

\begin{abstract}
In the last decade, the development of industry has fast progress, Rungkut Surabaya River is one of the waters that has potential to changes due to the discharge of liquid industrial waste. One of the contaminants that are harmful to health are lead $(\mathrm{Pb})$ and Chromium (Cr). Based on BSN in 2004 showed that lead standard $(\mathrm{Pb})$ levels about $1.5 \mathrm{mg} / \mathrm{kg}$ and metal $(\mathrm{Cr})$ about $1.0 \mathrm{mg} / \mathrm{kg}$. The purpose of this study was to analyze the Lead $(\mathrm{Pb})$ and Chromium $(\mathrm{Cr})$ levels in Kreco (Pila ampullacea) along the Rungkut river in Surabaya. The methods $\mathrm{Pb}$ and $\mathrm{Cr}$ test was carried out using the Atomic Absorption Spectrophotometer Shimadzu AA-6200 (SSA) with a wavelength of $283.3 \mathrm{~nm}$ for Pb and a wavelength of $357.9 \mathrm{~nm}$ for $\mathrm{Cr}$ that were done in the Surabaya Industrial Standardization Research Center with held from February 16 until March 13, 2019. Based on the results of the study showed that mean of $\mathrm{Pb}$ in Kreco meat about $1.620 \mathrm{mg} / \mathrm{kg}$ and mean of $\mathrm{Cr}$ about $1.976 \mathrm{mg} / \mathrm{kg}$. Pb and Cr levels in Kreco meat exceed of the standards determined by the National Standard Agency 2009.
\end{abstract}

Keywords: Lead (Pb), Chromium (Cr), Kreco, Surabaya Rungkut River, Spectrophotometer

\section{PENDAHULUAN}

Salah satu jenis Keong yang banyak di perairan sungai seringkali dikonsumsi oleh masyarakat sekitar di berbagai belahan dunia. Salah satu jenis keong yang banyak dikonsumsi oleh masyarakat adalah Kreco (Pila ampullacea). Kreco rebus menjadi salah satu makanan favorit masyarakat, terutama masyarakat di Jawa (Rostiyani, 2012). Kreco umumnya memiliki kandungan protein dan mineral yang cukup tinggi dan bermanfaat bagi metabolisme tubuh.

Kandungan protein dan mineral pada makanan menjadi unsur penting bagi kesehatan tubuh manusia. Protein memiliki fungsi untuk pertumbuhan dan pemeliharaan sel-sel tubuh, pengaturan keseimbangan air, pemeliharaan netralitas tubuh, pembentukkan antibodi, pengangkutan zat-zat gizi, dan sumber energi (Pangaribuan, 2013). Kekurangan protein menyebabkan penyakit kwashiorkor dan marasmus (Rostiyani 2012).

Dalam dekade terakhir, perkembangan industri telah mengalami kemajuan yang sangat pesat. Akibat proses industrialisasi tersebut menyebabkan buangan 
limbah industri berupa limbah cair, padat maupun gas yang dapat mengakibatkan terjadinya pencemaran lingkungan dalam bentuk limbah cair pada industri (Apriliani, 2010) yang dapat memberikan kontribusi terhadap pelepasan logam berat beracun di dalam aliran air seperti Timbal $(\mathrm{Pb})$ dan Kromium $(\mathrm{Cr})$ yang berdampak negatif pada makhluk hidup di lingkungan sekitarnya. Sungai Rungkut Surabaya merupakan salah satu perairan yang berpotensi mengalami perubahan lingkungan akibat adanya pembuangan limbah industri cair karena terdapat kompleks industry SIER (Surabaya Indutri Estase Rungkut). Limbah cair yang masuk ke perairan dapat bersifat toksik dan berakibat pada pencemaran lingkungan yang sangat besar (Jakfar, 2014) baik karena adanya kandungan logam berat atau zat kimia industri yang terkandung dalam air sungai.

Logam berat dapat memasuki tubuh melalui aktivitas makan, minum, dan pernapasan. Jika pada konsentrasi tinggi, logam berat dapat menyebabkan bahaya dan keracunan akibat bioakumulasi dalam tubuh (Akoto et al., 2008). Dampak akumulasi timbal $(\mathrm{Pb})$ dalam tubuh manusia yaitu pada anak dapat menyebabkan gangguan pada fase awal pertumbuhan fisik dan mental yang kemudian berakibat pada fungsi kecerdasan dan kemampuan akademik. Jika konsentrasi timbal $(\mathrm{Pb})$ meningkat, akan terjadi anemia dan kerusakan fungsi otak serta kegagalan fungsi ginjal sedangkan keracunan timbal $(\mathrm{Pb})$ pada orang dewasa ditandai dengan gejala seperti pucat, sakit dan kelumpuhan (Widowati, 2008).

Sedangkan dampak akumulasinya kromium (Cr) bagi tubuh dalam jumlah besar di dalam tubuh manusia dapat menyebabkan kanker, dan menghambat pertumbuhan janin dan menyebabkan mutagenic (Andini, 2017 ; Andini dan Aini, 2017 ; Schiavon et al., 2008). Dampak kromium (Cr) yang ditimbulkan bagi organisme akuatik yaitu terganggunya metabolisme tubuh akibat terhalangnya kerja enzim dalam proses fisiologis.

Kandungan timbal $(\mathrm{Pb})$ dan kromium (Cr) dalam air dapat memicu akumulasi logam berat pada organ biota di aliran sungai termasuk Kreco. Jika Kreco dikonsumsi oleh manusia, maka logam berat tersebut akan terakumulasi di dalam tubuh manusia.

Oleh karena itu, perlu dilakukan penelitian mengenai perbedaan kandungan logam berat timbal dan kromium pada Kreco (Bellamya Javanica) di sepanjang Sungai Rungkut surabaya dengan menggunakan spektrofotometer serapan atom (SSA) agar dapat menjadi bahan pertimbangan masyarakat setempat dan pabrikpabrik sekitar untuk lebih memperhatikan pengolahan limbahnya.

\section{METODE}

Penelitian ini merupakan penelitian observasional. Populasi yang digunakan adalah Kreco yang terdapat di sepanjang sungai Rungkut Surabaya. Sampel Kreco diambil dari sepanjang sungai Rungkut Surabaya pada 3 titik di 5 desa yaitu. Medokan, Wonorejo, Penjaringan, Pandugo, Kalirungkut

Teknik penentuan sampel Kreco yang digunakan adalah Purposive Sampling yaitu sampel penelitian ditentukan berdasarkan lokasi atau daerah yang terdapat Kreco di Sepanjang Sungai Rungkut Surabaya. 
Adapun kriteria inklusi yang digunakan yaitu cangkang berbentuk piramida dengan puncak yang tinggi dan dasar yang melingkar, cangkang berwarna hijau kecoklatan atau hijau kekuningan., Berat Kreco 10-20 gram, ukuran Kreco 5-8cm.

Alat penelitian yang digunakan meliputi Box sampel, rak gelas, Neraca analitik, pipet, Beaker glass $300 \mathrm{ml}$, Hot plate, Labu ukur 100ml, Kertas saring, corong, Erlenmeyer 100ml, Spetrofotometer Shimadzu AA-6200. Sedangkan bahan yang digunakan sampel Kreco, Aquadest, $\mathrm{HNO}_{3}$, $\mathrm{HCLO}_{4}$.

\section{Analisa dengan Spektrofotometer Serapan Atom}

Dalam melakukan uji kadar $\mathrm{Pb}$ dan Cr pada sampel daging Kreco (pila ampullacea) dengan menggunakan metode spektrofotometer serapan atom (SSA). Analisis logam berat $\mathrm{Pb}$ dan $\mathrm{Cr}$ memerlukan beberapa tahapan. Tahapan yang diperlukan yaitu, tahap preparasi, tahap destruksi, pembuatan larutan blanko dan pembacaan nilai $\mathrm{Pb}$, $\mathrm{Cr}$ dengan menggunakan spektrofotometri serapan atom (SSA).

Pada tahap awal yang dilakukan yaitu pembuatan larutan standart timbal $(\mathrm{Pb})$ dan kromium $(\mathrm{Cr})$. Pada tahap preparasi sampel bersihkan keong Kreco dari cangkangnya diambil bagian dagingnya kemudian potong daging Kreco menjadi kecil kecil lalu Sampel daging Kreco ditimbang kurang lebih 10 gr dengan beaker glass $250 \mathrm{ml}$ menggunakan timbangan analitik. Sampel Kreco yang telah ditimbang sampel akan dilakukan pemanasan dengan hotplate pada suhu $450^{\circ} \mathrm{C}$. Sebelum di panaskan sampel di tambahkan reagen $\mathrm{HNO}_{3} 250 \mathrm{ml}$ dan $\mathrm{HCLO}_{4} \quad 250 \mathrm{ml}$ tujuan untuk menghilangkan karbon yang mengikat oksigen dalam sampel. Kemudian persampel diberikan $\mathrm{HNO}_{3} 50 \mathrm{ml}$ dan $\mathrm{HCLO}_{4} 50 \mathrm{ml}$, Setelah dipanaskan selama kurang lebih 1 jam, lalu sampel dibiarkan dingin dan tidak ada uap Setelah didinginkan sampel dilakukan proses pelarutan menggunakan aquadest., kemudian sampel dimasukan kedalam labu ukur 100ml dan dibilas dengan aquadest setelah itu add kan sampai tanda batas, Setelah sampel dimasukan ke dalam labu ukur lalu di kocok kurang lebih 3-5 kali, Kemudian dilakukan proses penyaring dalam labu ukur $100 \mathrm{ml}$ menggunakan kertas saring whatman 40. Pada tahap selanjutnya dicuci menggunakan aquades agar sisa sisa yang menempel pada kertas saring ikut terlarut, ditambahkan aquades sampai tanda batas pada labu ukur $100 \mathrm{ml}$ dan kocok sampai homogen atau terlarut sempurna. Selanjutnya, lakukan hal yang sama terhadap blanko yang terdiri dari aquades $100 \mathrm{ml}$ dengan $\mathrm{HNO}_{3}$ 0,1 N 5ml (Andini dan Aini, 2017).

Pada tahapan pengujian kadar logam $\mathrm{Pb}$ dan $\mathrm{Cr}$ dilakukan dengan menggunakan Spektrofotometer Serapan Atom di Balai Riset Industri Standarisasi Surabaya. Setelah didapatkan hasil kadar logam dalam sampel, maka selanjutnya dilakukan konversi hasil yang dihitung dengan menggunakan rumus sebagai berikut. Kadar logam $(\mathrm{mg} / \mathrm{kg})=\underline{\text { Kons. Logam }(\mathrm{mg} / \mathrm{l}) \times 10^{-1}}$

\section{HASIL} Berat sampel $(\mathrm{kg}) \times 10^{-3}$

Adapun hasil pengukuran standart $\mathrm{Pb}$ dan $\mathrm{Cr}$ kurva kalibrasi pada berbagai konsentrasi yang berbeda diperoleh hasil sebagai berikut :

\section{Kadar Timbal (Pb)}

Pada penelitian uji kadar timbal $(\mathrm{Pb})$ daging Kreco di sepanjang sungai Rungkut dengan menggunakan metode spektrofotometri serapan atom pada panjang gelombang $283.3 \mathrm{~nm}$. 
Tabel 1. Absorbansi standar $\mathrm{Pb}$ dengan berbagai konsentrasi

\begin{tabular}{|c|c|}
\hline Standart $\mathrm{Pb}(\mathrm{ppm})$ & Abs. \\
\hline 0,05 & $-0,0001$ \\
\hline 0,1 & 0,0008 \\
\hline 0,2 & 0,0015 \\
\hline 0,5 & 0,0036 \\
\hline 1 & 0,0082 \\
\hline
\end{tabular}

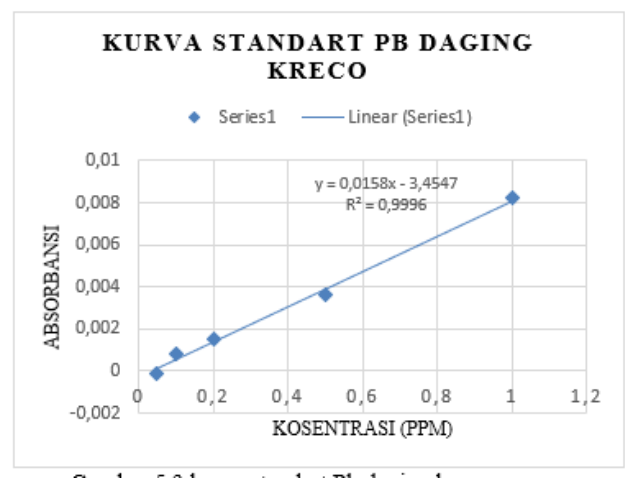

Gambar 1. Kurva standrt $\mathrm{Pb}$

Hasil pengukuran kadar $\mathrm{Pb}$ pada daging Kreco di kecamatan rungkut Surabaya terdapat pada label.

1 berikut :

\begin{tabular}{|c|c|c|c|c|c|c|}
\hline No & $\begin{array}{l}\text { Kode } \\
\text { Sampel }\end{array}$ & $\begin{array}{c}\text { Nilai } \\
\text { Absarbansi }\end{array}$ & $\begin{array}{c}\text { Kadar } \\
(\mathrm{mg} / \mathrm{ml})\end{array}$ & $\begin{array}{l}\text { Kadar Pb } \\
(\mathrm{mg} / \mathrm{kg})\end{array}$ & $\begin{array}{c}\text { Rata } \\
\text { rata } \\
(\mathrm{mg} / \mathrm{kg})\end{array}$ & Keterangan \\
\hline 1 & MDKN 1 & 0,0006 & 218,68 & 1,783 & \multirow{3}{*}{1,774} & $\begin{array}{c}\text { Tidak memenub } \\
\text { standar }\end{array}$ \\
\hline 2 & MDKN 2 & 0,0011 & 218,72 & 1,497 & & $\begin{array}{l}\text { Tidak memenub } \\
\text { standar }\end{array}$ \\
\hline 3 & MDKN 3 & 0,0009 & 218,70 & 2,043 & & $\begin{array}{l}\text { Tidak memeaub } \\
\text { standar }\end{array}$ \\
\hline 4 & WNRJ 1 & 0,0005 & 218,68 & 2,013 & \multirow{3}{*}{1,991} & $\begin{array}{c}\text { Tidak memenub } \\
\text { standar }\end{array}$ \\
\hline 5 & WNRJ 2 & 0,0004 & 218,67 & 1,923 & & $\begin{array}{c}\text { Tidak memenub } \\
\text { standax }\end{array}$ \\
\hline 6 & WNRJ 3 & 0,0006 & 218,68 & 1,918 & & $\begin{array}{c}\text { Tidak memenub } \\
\text { standar }\end{array}$ \\
\hline 7 & PNJR 1 & 0,0006 & 218,68 & 2,021 & \multirow{3}{*}{1,609} & $\begin{array}{c}\text { Tidal memenub } \\
\text { standar }\end{array}$ \\
\hline 8 & PNJR 2 & 0,0004 & 218,69 & 1,531 & & $\begin{array}{c}\text { Tidak memenub } \\
\text { standar }\end{array}$ \\
\hline 9 & PNJR 3 & 0,0008 & 218,67 & 1,275 & & $\begin{array}{c}\text { Tidak memenub } \\
\text { standar }\end{array}$ \\
\hline 10 & PNDGO 1 & 0,0007 & 218,69 & 1,5 & \multirow{3}{*}{1,656} & $\begin{array}{c}\text { Tidak memenub } \\
\text { standar }\end{array}$ \\
\hline 11 & PNDGO 2 & 0,0010 & 218,71 & 1,942 & & $\begin{array}{l}\text { Tidak memenub } \\
\text { standar }\end{array}$ \\
\hline 12 & PNDGO 3 & 0,0006 & 218,68 & 1,810 & & $\begin{array}{c}\text { Tidak memenub } \\
\text { standar }\end{array}$ \\
\hline 13 & $\begin{array}{c}\text { KALRUG } \\
1\end{array}$ & $-0,0004$ & 218,62 & 1,528 & \multirow{3}{*}{1,656} & $\begin{array}{c}\text { Tidak memenub } \\
\text { standar }\end{array}$ \\
\hline 14 & $\begin{array}{c}\text { KALRUG } \\
2\end{array}$ & 0,0002 & 218,66 & 1,4 & & $\begin{array}{c}\text { Tidak memenub } \\
\text { standar }\end{array}$ \\
\hline 15 & $\begin{array}{c}\text { KALRUG } \\
3 \\
\end{array}$ & $-0,0025$ & 218,49 & 2,041 & & $\begin{array}{c}\text { Tidalak memenub } \\
\text { standar }\end{array}$ \\
\hline
\end{tabular}

Berdasarkan tabel 1 dapat diketahui seluruh sampel daging Kreco Medokan (MDKN), Wonorejo (WNRJ), Penjaringan (PNJR), Pandugo (PNDGO) dan Kalirungkut (KALRUG) di kawasan Rungkut
Surabaya hasil didapat kadar melebihi batas standart yang di tentukan, karena memiliki nilai kandungan $\mathrm{Pb}$ yang tinggi yaitu diatas Badan Standart Nasional 2009 adalah 1,5 mg/kg.

\section{Kadar Kromium}

Pada penelitian uji kadar kromium (Cr) daging Kreco di sepanjang sungai rungkut dengan menggunakan metode spektrofotometri serapan atom dengan panjang gelombang $357.9 \mathrm{~nm}$.

Tabel 2. Absorbansi standar $\mathrm{Pb}$ dengan berbagai konsentrasi

\begin{tabular}{|c|c|}
\hline Standart Cr (ppm) & Abs. \\
\hline 0,2 & 0,0057 \\
\hline 0,2 & 0,0102 \\
\hline 0,4 & 0,0180 \\
\hline 0,8 & 0,0369 \\
\hline 1 & 0,0446 \\
\hline
\end{tabular}

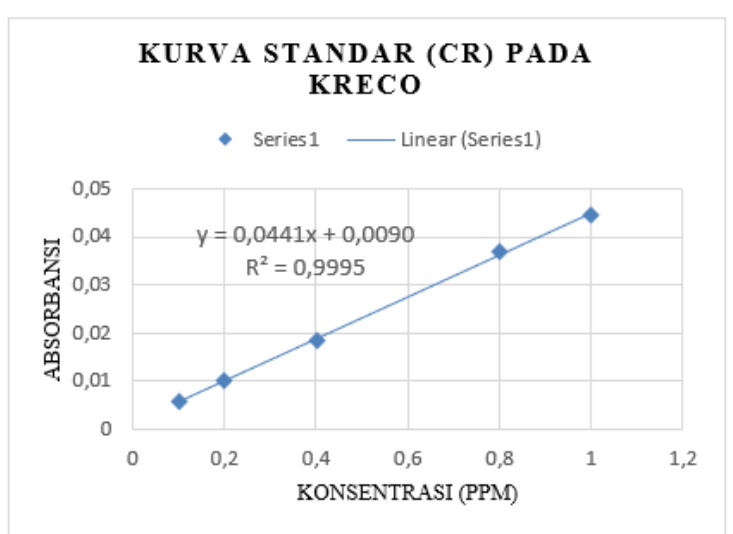

Gambar 2. Kurva standrt Cr

Hasil pengukuran kadar $\mathrm{Pb}$ pada daging Kreco di kecamatan rungkut Surabaya terdapat pada label. 2 berikut : 


\begin{tabular}{|c|c|c|c|c|c|c|}
\hline No & $\begin{array}{l}\text { Kode } \\
\text { Sampel }\end{array}$ & $\begin{array}{c}\text { Nilai } \\
\text { Absarbansit }\end{array}$ & $\begin{array}{l}\text { Kadar } \\
(\mathrm{mg} / 1)\end{array}$ & $\begin{array}{c}\mathrm{Kadar} \mathrm{Cr} \\
(\mathrm{mg} / \mathrm{kg})\end{array}$ & $\begin{array}{c}\text { Rata } \\
\text { rata } \\
(\mathrm{mg} / \mathrm{kg})\end{array}$ & Keterangan \\
\hline 1 & MDKN 1 & 0,0033 & 0,2789 & 2,274 & \multirow{3}{*}{2,231} & $\begin{array}{l}\text { Tidalk mementw } \\
\text { standar }\end{array}$ \\
\hline 2 & $\mathrm{MDKN} 2$ & 0,0020 & 0,2494 & 1,707 & & $\begin{array}{l}\text { Tidal memeen } \\
\text { standar }\end{array}$ \\
\hline 3 & MDKN 3 & 0,0038 & 0,2902 & 2,712 & & $\begin{array}{c}\text { Tidalk mement } \\
\text { standdr }\end{array}$ \\
\hline 4 & WNRJ 1 & 0,0030 & 0,2721 & 2,505 & \multirow{3}{*}{2,520} & $\begin{array}{l}\text { Tidalk mement } \\
\text { standar }\end{array}$ \\
\hline 5 & WNRJ 2 & 0,0030 & 0,2721 & 2,393 & & $\begin{array}{c}\text { Tidak memen } \\
\text { standar }\end{array}$ \\
\hline 6 & WNRJ 3 & 0,0044 & 0,3038 & & & $\begin{array}{c}\text { Tidalk mamen } \\
\text { standar }\end{array}$ \\
\hline 7 & PNJR 1 & 0,0005 & 0,2154 & 1,990 & \multirow{3}{*}{1,557} & $\begin{array}{c}\text { Tidal mement } \\
\text { standar }\end{array}$ \\
\hline 8 & PNJR 2 & 0,0004 & 0,2131 & 1,492 & & $\begin{array}{c}\text { Tidal menden } \\
\text { standar }\end{array}$ \\
\hline 9 & PNJR 3 & 0 & 0,2040 & 1,190 & & $\begin{array}{l}\text { Tidal memeen } \\
\text { standar }\end{array}$ \\
\hline 10 & PNDGO 1 & 0,0016 & 0,2403 & 1,536 & \multirow{3}{*}{1,782} & $\begin{array}{c}\text { Tidalk memeen } \\
\text { standar }\end{array}$ \\
\hline 11 & PNDGO 2 & 0,0008 & 0,2222 & 1,973 & & $\begin{array}{c}\text { Tidalk memen } \\
\text { standar }\end{array}$ \\
\hline 12 & PNDGO 3 & 0,0008 & 0,2222 & 1,839 & & $\begin{array}{c}\text { Tidal mement } \\
\text { standar }\end{array}$ \\
\hline 13 & $\begin{array}{c}\text { KALRUG } \\
1\end{array}$ & 0,0018 & 0,2448 & 1,6 & \multirow{3}{*}{1,788} & $\begin{array}{c}\text { Tidalk memen } \\
\text { standar }\end{array}$ \\
\hline 14 & $\begin{array}{c}\text { KALRUG } \\
2\end{array}$ & 0,0016 & 0,2403 & 1,521 & & $\begin{array}{c}\text { Tidak mement } \\
\text { standar }\end{array}$ \\
\hline 15 & $\begin{array}{c}\text { KALRUG } \\
3\end{array}$ & 0,0019 & 0,2471 & 2,245 & & $\begin{array}{l}\text { Tidalk mement } \\
\text { standar. }\end{array}$ \\
\hline
\end{tabular}

Berdasarkan tabel 5.3 dapat diketahui seluruh sampel daging Kreco Medokan (MDKN), Wonorejo (WNRJ), Penjaringan (PNJR), Pandugo (PNDGO) dan Kalirungkut (KALRUG) di kawasan Rungkut Surabaya dalam kadar yang melebihi batas standart yang di tentukan, karena memiliki nilai kandungan $\mathrm{Cr}$ yang tinggi yaitu diatas Badan Standart Nasional 2009 adalah $1,0 \mathrm{mg} / \mathrm{kg}$.

\section{PEMBAHASAN}

Berdasarkan hasil penelitian uji laboratorium, kandungan logam berat timbal $(\mathrm{Pb})$ dan kromium $(\mathrm{Cr})$ yang terdapat dalam Kreco (Pila ampullacea) yang diambil dari beberapa tempat yang berbeda di kecamatan Rungkut Surabaya, dari hasil penelitan yang didapatkan terhadap kandungan logam timbal $(\mathrm{Pb})$ pada kreco diperoleh hasil rata rata kadar $\mathrm{Pb}$ yaitu, MDKN 1,774 mg/kg sampel berdekatan rongsokan dan jalan besar, WNRJ $1,991 \mathrm{mg} / \mathrm{kg}$ sampel berdekatan bengkel dan jalan besar PNJR 1,609 mg/kg, PNDGO 1,656 $\mathrm{mg} / \mathrm{kg}$ sampel berdekatan POM bensin dan jalan besar, KALRUG 1,656 $\mathrm{mg} / \mathrm{kg}$ sampel berdekatan jalan besar. Hasil tersebut diatas nilai standard yang telah ditetapkan oleh badan standart nasional 2009 dan keputusan pengawas obat dan makanan no.03725/B/SK/VII/1989 untuk kadar maksimum timbal $(\mathrm{Pb})$ pada moluska adalah 1,5 mg/kg. Dari kandungan logam berat timbal tertinggi pada Kreco didapatkan rata rata pada wilayah WNRJ sebanyak 1,991 mg/kg dikarenakan wilayah pengambilan dekat dengan jalan raya dan bengkel sedangkan kandungan logam berat timbal terendah pada Kreco didapatkan rata rata pada wilayah PNJR sebanyak $1,609 \mathrm{mg} / \mathrm{kg}$.

konsentrasi logam timbal $(\mathrm{Pb})$ yang tinggi terdapat pada Kreco yang memiliki kelompok ukuran besar. Hal ini diduga karena besar cangkang suatu spesies makrofauna bentik biasanya identik dengan umur spesies tersebut, artinya semakin besar ukuran cangkang maka umur spesies tersebut juga diperkirakan lebih tinggi, sehingga waktu akumulasi logam berat telah berlangsung lebih lama dibandingkan Kreco dengan ukuran cangkang kecil. Timbal (Pb) merupakan logam berat yang mempunyai daya toksitas yang tinggi terhadap manusia apabila manusia mengkonsumsi Kreco yang mengandung logam berat dalam jumlah yang cukup tinggi akan berdampak negatif terhadap kesehatan karena dapat merusak perkembangan otak pada anak-anak, menyebabkan penyumbatan sel-sel darah merah, anemia dan mempengaruhi anggota tubuh lainnya.

Sedangkan pada hasil penelitan laboratorium kandungan logam berat $\mathrm{Cr}$ pada daging Kreco di beberapa tempat yang berbeda terdapat 3 titik 5 desa disepanjang sungai rungkut Surabaya. Dari hasil penelitan yang didapatkan terhadap kandungan kromium (Cr) pada kreco diperoleh hasil kadar $\mathrm{Cr}$ yaitu,MDKN 2,231 $\mathrm{mg} / \mathrm{kg}$, WNRJ 2,520 $\mathrm{mg} / \mathrm{kg}$, PNJR $1,557 \mathrm{mg} / \mathrm{kg}$, PNDGO $1,782 \mathrm{mg} / \mathrm{kg}$, 
KALRUG 1,788 mg/kg. Hasil tersebut diatas nilai standar yang telah ditetapkan oleh badan standar nasional 2009 dan keputusan pengawas obat dan makanan no.03725/B/SK/VII/1989 untuk kadar maksimum kromium $(\mathrm{Cr})$ pada Kreco adalah $1,0 \mathrm{mg} / \mathrm{kg}$. Dari kandungan logam berat timbal tertinggi pada Kreco didapatkan rata rata pada wilayah WNRJ sebanyak 2,520 $\mathrm{mg} / \mathrm{kg}$ dikarenakan wilayah pengambilan dekat dengan jalan raya dan bengkel sedangkan kandungan logam berat timbal terendah pada Kreco didapatkan rata rata pada wilayah PNJR sebanyak $1,557 \mathrm{mg} / \mathrm{kg}$. salah satu faktor utama yang mempengaruhi tingginya kadar logam berat $(\mathrm{Cr})$ kromium. Karena logam berat akan mengendap di substrat atau lumpur dalam waktu yang lama. Sehingga organisme yang hidup pada substrat tersebut akan terkontaminasi dengan waktu yang lama dan dengan konsentrasi yang tinggi serta mengingkatkan tingginya kandungan logam berat pada organisme tersebut.

Terakumulasinya kromium dalam jumlah besar di tubuh manusia akan mengganggu kesehatan karena kromium memiliki dampak negatif terhadap organ hati, ginjal serta bersifat racun bagi protoplasma makhluk hidup. Selain itu juga berdampak sebagai karsinogen (penyebab kanker), teratogen (menghambat pertumbuhan janin) dan mutagen (Schiavon et al., 2008). Akumulasi logam berat kromium $(\mathrm{Cr})$ dapat menyebabkan kerusakan terhadap organ respirasi dan dapat juga menyebabkan timbulnya kanker pada manusia (Suprapti 2008).

Berdasarkan hasil penelitian kandungan logam berat timbal dan kromium pada daging Kreco di sepanjang sungai rungkut Surabaya rata rata melebihi standart yang di tentukan. Kreco sangat potensial sebagai indikator terkontaminasi logam berat mengingat asupanya yang bersifat penyaring makanan (filter feeder). Di samping itu, sifat Kreco ini lebih banyak menetap dan bukan termasuk migratory. Hal tersebut akan terjadi akumulasi unsur unsur kimia di dalam tubuh.

\section{KESIMPULAN DAN SARAN \\ Kesimpulan}

1. Rata-rata kadar timbal $(\mathrm{Pb})$ pada daging Kreco di sepanjang sungai Rungkut Surabaya yaitu Medokan $1,774 \mathrm{mg} / \mathrm{kg}$, Wonorejo 1,991 $\mathrm{mg} / \mathrm{kg}$, Penjaringan 1,609 mg/kg, Pandugo $\quad 1,656 \quad \mathrm{mg} / \mathrm{kg}$, Kalirungkut 1,656 mg/kg.

2. Rata-rata kadar kromium (Cr) pada daging Kreco di sepanjang sungai Rungkut yaitu Medokan 2,231 $\mathrm{mg} / \mathrm{kg}$, Wonorejo 2,520 $\mathrm{mg} / \mathrm{kg}$, Penjaringan $1,557 \mathrm{mg} / \mathrm{kg}$, Pandugo $1,782 \quad \mathrm{mg} / \mathrm{kg}$, Kalirungkut 1,788 mg/kg.

3. Kadar $\mathrm{Pb}$ dan kadar $\mathrm{Cr}$ tertinggi terletak di Kawasan Sungai Wonorejo sedangkan terendah terletak di Kawasan Penjaringan. Hasil analisa menunjukkan kadar $\mathrm{Pb}$ dan $\mathrm{Cr}$ pada Kreco di sepanjang sungai Rungkut tidak memenuhi standart yang telah ditentukan oleh Badan Standart Nasional 2009.

\section{Saran}

Perlu adanya penelitian lanjutan mengenai spesies biota lainnya yang juga banyak ditemukan di sepanjang sungai Rungkut Surabaya

\section{REFERENSI}

Akoto, O., Bruce, T. N., Darkol, G. 2008, Heavy metals pollution profiles in streams serving the Owabi reservoir. African Journal 
of Environmental Science and Technology, 2 (11) : 354-359.

Andini A, 2017, “Analisa Cr(VI) Air di Kecamatan Tanggulangin, Sidoarjo". SainHealth Vol. 1 No. 2

Andini A, Aini SD, 2017, Hubungan Kadar $\mathrm{Cr}$ dalam Air Tambak terhadap $\mathrm{Cr}$ Pada Ikan Nila (Oreochromis niloticus), Ikan Bandeng (Chanos chanos) dan Udang Vaname (Litopenaeus vannamei) di Kawasan Jabon Sidoarjo. Journal of Medical Laboratory Science/Technology, 1 (2), Desember 2017, 1-16

Apriliani A. 2010. Pemanfaatan Arang Ampas Tebu Sebagai Adsorben Ion Logam $\mathrm{Cd}, \mathrm{Cr}, \mathrm{Cu}$ Dan $\mathrm{Pb}$ Dalam Air Limbah, Skripsi, Fakultas Sains dan Teknologo Program studi kimia. Universitas Uslam Negeri Syarid Hidayatullah Jakarta.

Jakfar, Agustono, 2014. Deteksi Logam Timbal $(\mathrm{Pb})$ Pada Ikan Nila (Oreochromis Niloticus) Di Sepanjang Sungai Kalimas Surabaya. Jurnal Ilmiah Perikanan dan Kelautan, Vol. 6 No 1.

Pangaribuan. 2013. Pengaruh Media perebusan terhadap komposisi kimia, asam amino, Mineral dan nilai sensori Keong tutut (bellamya javanica). Skripsi, Fakultas perikanan dan ilmu kelautan, Institut pertanian Bogor, Bogor

Schiavon, M. E. A. H. Pilon. Smits, M. Wirtz, R. Hell and M. Malagoli. 2008. Interactions Between Chromium And Sulfur Metabolism In Brassica juncea. Journal of Enviromental Quality. 37 : 15361545.

Suprapti, N. H.2008. Kandungan Chromium pada Sedimen dan Kerang Darah (Anadara granosa) di Wilayah Pantai Sekitar Muara Sungai Sayung, Desa Morosari
Kabupaten Demak Jawa Tengah. Bioma J. 10 (2) : 53-56

Widowati, H. 2008. Pengaruh Kadar Logam $\mathrm{Cd}, \mathrm{Pb}$ Terhadap Perubahan Warna Batang dan Daun Sayuran. El Hayah Vol.1 No 4 :167-173 